\title{
Late holocene environments in Las Tablas de Daimiel (south central Iberian peninsula, Spain)
}

\begin{abstract}
The use of a high resolution pollen record in combination with geochemical data from sediments composed mainly of layers of charophytes alternating with layers of vegetal remains plus some detrital beds permits the reconstruction of the environmental evolution of the last 3000 years in an inland wetland of the Mediterranean domain, thus introducing a new climatic dataset for the Late Holocene. Hydrological fluctuations, reflected in the relationship between emerged and aquatic vegetation and inorganic and organic $\mathrm{C}$ and $\mathrm{N}$ changes, can be related to aridity or humid phases, while relations among arboreal taxa (Quercus and Pinus) and Artemisia are used as temperature indicators. Five climatic periods have been identified: a Subatlantic Cold Period ( $<150$ B.C.), cold and arid; the Roman Warm Period (150 B.C.-A.D. 270), warmer and wetter; the Dark Ages (A.). 270-A.D. 950), colder and drier; the Medieval Warm Period (A.D. 950-A.D. 1400), warmer and wetter; and the Little Ice Age (>A.D. 1400) indicated by a cooling and drying trend. Despite the lack of any direct evidence of human action, there are some episodes related to deforestation during the Reconquista (Middle Ages) that mask the real climatic signal.
\end{abstract}

Keywords Pollen - Late Holocene - Environmental changes $\cdot$ Mediterranean area

M. J. Gil García (四) M. B. Ruiz Zapata

Department of Geology, University of Alcalá,

28871 Alcalá de Henares (Madrid), Spain

e-mail: mjose.gil@uah.es

J. I. Santisteban · C. J. Dabrio

Department of Stratigraphy, University Complutense of Madrid, 28040 Madrid, Spain

R. Mediavilla

Dirección de Geología y Geofísica, Instituto Geológico y

Minero de España,

28760 Tres Cantos (Madrid), Spain

E. López-Pamo

Dirección de Recursos Minerales y Geoambiente, Instituto Geológico y Minero de España,

28003 Madrid, Spain

\section{Introduction}

There has been an increasing interest in Late Holocene climate variability during recent years that is reflected, for example, in the IPCC (2001) report. This states "There is emerging evidence for significant, rapid (timescales of several decades or more), regional temperature changes during the last 10,000 years. However, the evidence does not indicate that any such events were global in scale" (Folland et al. 2001); this includes periods like the "Little Ice Age" or the "Medieval Warm Period" (IPCC 2001, pp 133-136). However there is still debate about the procedures used to reach those conclusions and their validity (Soon and Baliunas 2003; Soon et al. 2003; McIntyre and McKitrick $2003,2005)$. Apart from the numerical procedures used for data analysis, there is one key fact that affects the truly "global" validity of the global palaeoclimatic reconstructions: "there are still only a small number of long, welldated, high-resolution proxy records" (Briffa and Osborn 1999). This is true in two main senses, the spatial coverage is very heterogeneous and the number of proxies used in studies of global climate change is low.

The Iberian Peninsula is unique as it is located at the intersection between the Mediterranean and the Atlantic, Europe and Africa and is consequently affected by all of them. Because of its geodynamic position, its tectonic evolution is very complex and this is reflected in a very variable topography. As a result the variability of environments and records is very high. Despite this, research has centred on similar environments to those of north and central Europe (peat bogs, high altitude lakes, deep lakes) while multiproxy study of many of the unusual systems existing in the Iberian Peninsula (saline lakes, temperate middle and low altitude biogenic lakes, etc.) did not begin until recently.

For example, Martínez-Cortizas et al. (1999), using variations in $\mathrm{Hg}$ in a peat bog in NW Spain found evidence of some important climate changes during the last 4000 years. Valero-Garcés et al. $(1999,2000)$ identified variations in saline lake levels in NE Spain related to the end of the Medieval Warm Period. Luque and Julià (2002) attributed 
most of the variations found in the sediments for the last 1000 years from the Lake Sanabria (NW Spain) to human activity, but were able to identify the Little Ice Age. Desprat et al. (2003) recognised the classical climate episodes for recent times (First Cold Period of the Subatlantic, Roman Warm Period, Dark Ages, Medieval Warm Period, Little Ice Age, Recent Warming) in the pollen record of the last 3000 years from the Ría de Vigo (NW Spain). More recently, Riera et al. (2004) carried out a study very similar to that presented in this paper. They used a multiproxy approach to reconstruct the last 2000 years of lake level variations in the Estanya lakes (NE Spain), differentiating between the human record and the climate record, and also clearly identifying the Medieval Warm Period and the Little Ice Age. González-Alvarez et al. (2005), in a multiproxy study of the last $\mathbf{3 0 0 0}$ years on the Galician continental shelf (NW Spain), identified two periods of contrasting environmental conditions. They found that during the Subboreal/Subatlantic transition $(2850 \mathrm{cal}$ B.P.) conditions were stormy in comparison to those during the following Subatlantic and they identified an upwelling related to the cooling of oceanic waters at around A.D. 1420, probably linked to the colder temperatures of the Little Ice Age.

Despite the incomplete record from the Iberian Peninsula, there is considerable evidence of climate oscillations during the last $\mathbf{3 0 0 0}$ years. These records show slight differences but this could be due to environmental factors as well as the complexity of the vegetation dynamics. Against this background the present paper describes a high-resolution study developed in a relatively continuous record from inland Spain and in particular tries to analyse the response of the vegetation to such changes with the help of the geochemical record.

\section{Study site}

The study area is located in the La Mancha Plain, within the South-central Iberian Peninsula (Fig. 1). The La Mancha Plain corresponds to an E-W morphostructural depression in which Cainozoic terrestrial deposits overlie the Paleozoic (to the W) and Mesozoic basement. Unlike other Tertiary basins in the Iberian Peninsula, this depression has smaller dimensions and a younger sedimentary filling.

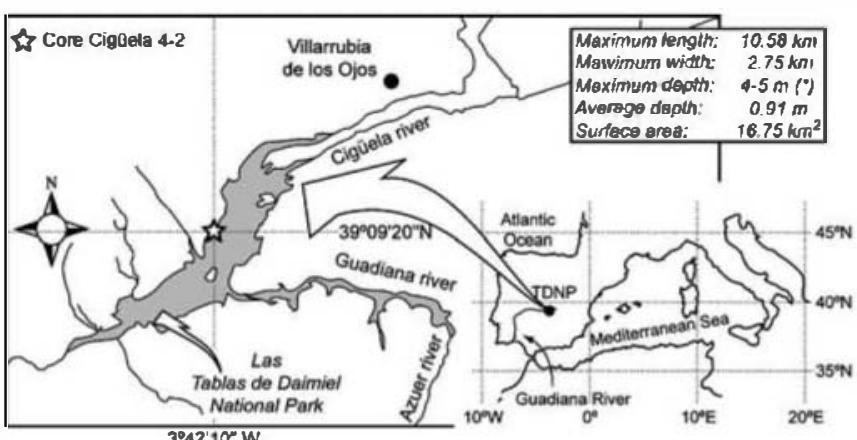

Fig. 1 Location of Las Tablas de Daimiel National Park and the core Cigiela 4-2. TDNP: Las Tablas de Daimiel National Park
The potential vegetation in the La Mancha Plain is typically Mediterranean, made up of Quercus retundifolia (evergreen oak) forest together with Arbutus unedo, Phillyre angustifolia, Rhamnus alaternus, Pistacia terebinthus and Res canina. At present, the vegetation consists of evergreen oak forests (Quercus rotundifolia), cleared and used as "dehesas" (forests of evergreen oak with tree-cover lower than $40 \%$ and with cleared spaces used for cultivation or pastures), together with extensive cultivation zones (Peinado-Lorca and Rivas-Martínez 1987).

The Las Tablas de Daimiel National Park is a fluvial wetland or open lake linked to the Gigiela and Guadiana rivers, located at $605 \mathrm{~m}$ a.s.1. in central Spain (Fig. 1). The present-day system is fed by sulphated waters from the Gigiela River, but since 1983 the Guadiana River has supplied carbonated surface and groundwaters. The climate is temperate Mediterranean with dry and hot summers and cold winters. Hydrologically, the system is controlled by high seasonal rainfall. In a typical year, the wetland is flooded for seven months, being almost dry for the rest of the year.

In this paper we present palynological and lithological data from the core Cigiiela 4-2 located in Las Tablas de Daimiel National Park (Fig. 1). Four other pollen sequences obtained from this area have been investigated previously. The first of these is Daimiel II, covering about the last 3200 years ( $3190 \pm 70$ в.P.; $1628-1305$ в.C.) although information is limite by the low quantity of pollen grains in almost all samples (Menéndez-Amor and Florschütz 1968) and the absence of pollen from several sections. The second, Castillo de Calatrava, covers only about the last 6300 B.P. $(6240 \pm 190$ в.P.; $5536-4727$ в.C.; García-Antón et al. 1986). The third, core CC-17, provides palaeoclimatic information since Late-glacial/Holocene transition (DoradoValiño et al. 1999, 2002) and the fourth, core TD, corresponds to the Last Glacial Cycle (Valdeolmillos et al. 2003).

\section{Material and methods}

During December 2002, a coring campaign was carried out in the Las Tablas National Park yielding 40 cores taken from 15 coring sites. Five master points were selected and in each one two "dry" rotation cores $(9 \mathrm{~cm}$ in diameter) were drilled and two manual PVC cores $(11 \mathrm{~cm}$ in diameter, $1 \mathrm{~m}$ in length) were made to recover the uppermost part. As result we obtained a composite core for visual study and sampling (one of which is core Ciguiela 4-2, Fig. 1). Once in the laboratory, the cores were opened, photographed and the stratigraphy recorded. With these data and the scanned photographs, a detailed stratigraphical section (scale 1:1) was prepare for use during sampling. Sampling was performed with a guillotine of our own design adapted to the shape of our cores. Samples were taken contiguously with an average thickness of $0.7 \mathrm{~cm}$, each sample being split for the different analyses. After sampling a new stratigraphical section (Fig. 2) was constructed with lineally corrected 
Fig. 2 Core Cigiiela 4-2. Facies, vegetation-related geochemical parameters and dated samples

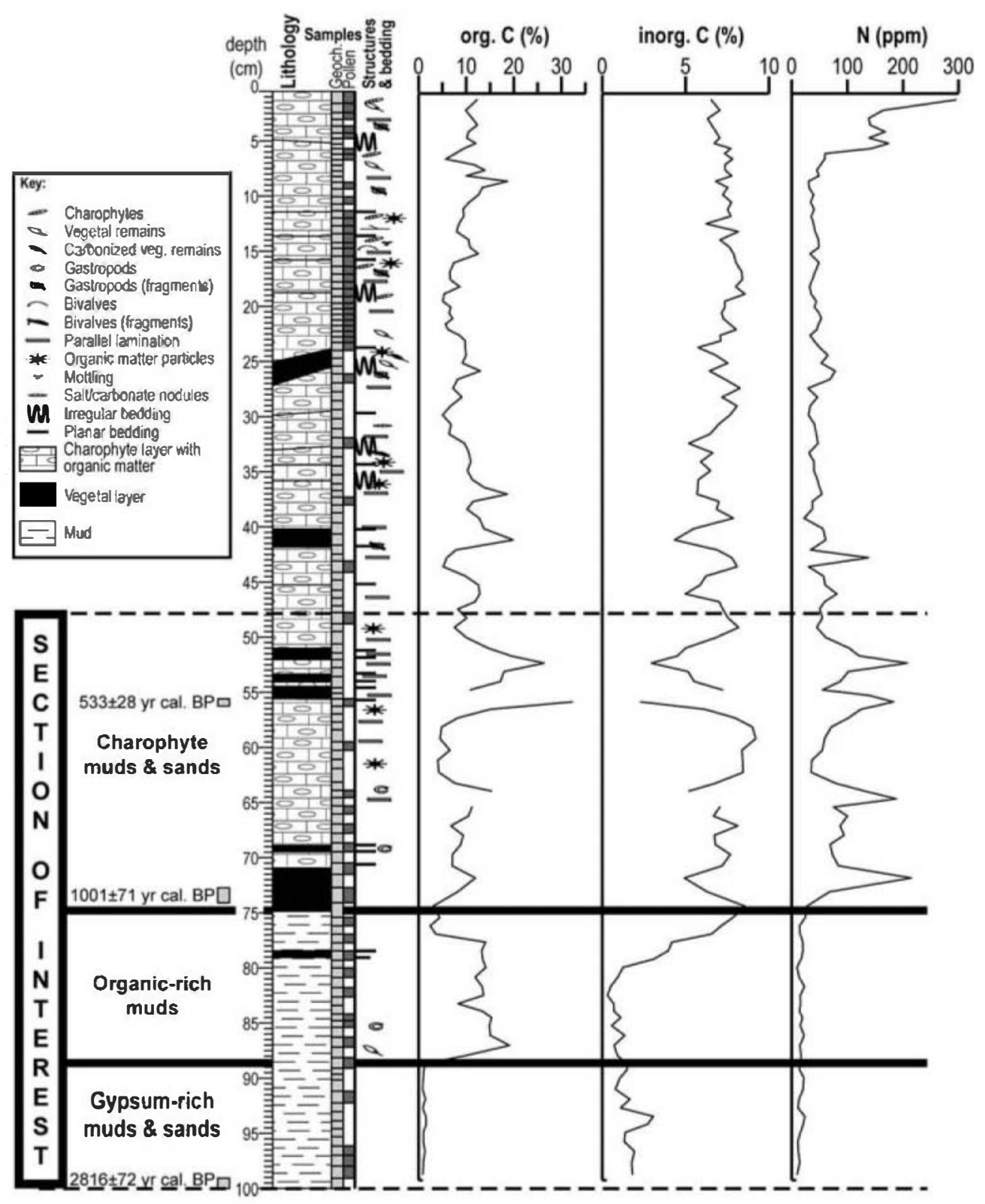

depths and sample thicknesses (correcting for the mechanical compaction produced by coring).

Samples for geochemistry were sent to ALS Chemex laboratories in Vancouver (Canada) where they were analysed for total carbon content (measured with a Leco SC-444DR carbon and sulphur analyser), inorganic carbon (measured by $\mathrm{CO}_{2}$ coulometry with an UIC ${ }^{\bullet} \mathrm{CM} 140$ Total Inorganic Carbon Analyzer) and organic carbon (calculated as the difference between total and inorganic $\mathrm{C}$ ). $\mathrm{N}$ was determined as extractable $\mathrm{N}\left(\mathrm{NH}_{4}\right.$, using a Technicon Autoanalyser $\bullet$, and $\mathrm{NO}_{3}$, colorimetrically using the CTA method) at ALS Environ Labs (Vancouver, Canada).

AMS ${ }^{14} \mathrm{C}$ dating of samples was done at the GADAM Centre (Gliwice, Poland) and ${ }^{239},{ }^{240} \mathrm{Pu}$ and ${ }^{210} \mathrm{Po}$ at the Centro de Investigaciones Medioambientales (CIEMAT, Madrid, Spain). Bulk samples were used as there was no evidence of contamination and all the $\mathrm{C}$ sources were biological (vegetal remains and bio-induced carbonates). The selection of samples was determined by their stratigraphical position and lack of evidence of contamination. The AMS dates were calibrate with CALIB v.4.4.2 (Stuiver and Reimer 1993; Stuiver et al. 2003) using the calibration datasets cited in Table 1 . Additionally, the ${ }^{210} \mathrm{Po}$ and ${ }^{239,}{ }^{240} \mathrm{Pu}$ profiles confirmed that there was no evidence of mixing of sediment or of hiatuses in the uppermost $20 \mathrm{~cm}$, as was also indicated from visual inspection of the cores. An age-depth model was constructed from these data and was tested against known (documentary) events recognisable in the sediments. From this a final recalibrated model was obtained. A good indication of the quality of the material was the fact that only minor adjustments were made to the age-depth model and these were probably related to the linear nature of the thickness correction method that does not allow for lack of homogeneity in the lithology. 
Table 1 Radiocarbon data. Calibration was performed with CALIB v.4.4.2 (Stuiver and Reimer 1993; Stuiver et al. 2003) using calibration data from Stuiver and Braziunas (1993), Stuiver et al. (1998a, b) and McCormac et al. (2002)

\begin{tabular}{|c|c|c|c|c|c|}
\hline Lab. code & Sample & $\begin{array}{l}\text { Depth } \\
\text { (m) }\end{array}$ & $\begin{array}{l}{ }^{14} \mathrm{C} \text { age } \\
\text { (yr B.P.) }\end{array}$ & $\begin{array}{l}\text { cal ages, } 2 \sigma \\
\text { (cal B.P.) }\end{array}$ & $\begin{array}{l}\text { probability } \\
\text { distribution }\end{array}$ \\
\hline \multirow[t]{2}{*}{ GdA-308 } & $4-2-79$ & 0.56 & $521 \pm 37$ & $\begin{array}{r}\text { A.D. } \begin{array}{r}1321-1351 \\
(599-629)\end{array}\end{array}$ & 0.169 \\
\hline & & & & $\begin{array}{r}\text { A.D. } 1389-1445 \\
(505-561)\end{array}$ & 0.831 \\
\hline \multirow[t]{3}{*}{ GdA-309 } & $4-2-101$ & 0.73 & $1098 \pm 39$ & $\begin{array}{r}\text { A.D. } 784-787 \\
(1163-1166)\end{array}$ & 0.003 \\
\hline & & & & $\begin{array}{l}\text { A.D. 833-836 } \\
(1114-1117)\end{array}$ & 0.003 \\
\hline & & & & $\begin{array}{r}\text { A.D. } 877-1020 \\
(930-1073)\end{array}$ & 0.994 \\
\hline \multirow[t]{2}{*}{ GdA-306 } & $4-2-132$ & 0.99 & $2699 \pm 53$ & $\begin{array}{l}972-957 \text { B.C. } \\
(2906-2921)\end{array}$ & 0.028 \\
\hline & & & & $\begin{array}{r}\text { 939-795 B.C. } \\
(2744-2888)\end{array}$ & 0.972 \\
\hline
\end{tabular}

Data analyses were performed using R statistical soft ware (R Development Core Team 2005).

Samples were prepared for pollen analysis using standard palynological methods (Faegri et al. 1989; Moore et al. 1991). A total terrestrial pollen sum $(>250)$ was used in calculating percentages. The pollen percentages for each taxon are based on the main pollen sum that excludes aquatic plants and pteridophyte spores because of their over-representation in these deposits. Spores and aquatic pollen percentages were obtained from the total sum (pollen + spores). Pollen ata are presented as the relative pollen frequency of each taxon in the pollen diagram (Fig. 3) prepare using the TILIA $\bullet$ and TILIA-GRAPH・ ( Eric C. Grimm) computer programs. The representation of all taxa in the pollen diagram has been exaggerated (shading) twice. Local pollen assemblage zones in the sense of Reille (1990) were recognised on the basis of changes in the representation of at least two ecologically significant taxa (Watts 1973; Reille 1990).

Vegetation indexes were also constructed as they give guidance on the environmental variables (Fig. 4). Thus, the arboreal vs. non-arboreal pollen (AP/NAP) is used as a key for moisture. The ratio of evergreen Quercus to the sum of Pinus and Artemisia is considered indicative of the temperature. Finally, the ratio of hydrophytes to hygrophylles reflects the extent of the open area of the water body (the area not occupied by aquatic-emergent vegetation).

Three main facies were identified by visual inspection of the cores (Fig. 2): (1) gypsum-rich siliciclastic muds and sands, changing at $88.5 \mathrm{~cm}$ (corrected depth) to (2) organic muds, and from $74.5 \mathrm{~cm}$ upwards, (3) alternation of Charophyte layers with organic matter laminae (of vegetal origin). The Principal Component Analysis of geochemical and mineralogical data confirmed this division by coincidence of the main PCs with sample visual facies (Santisteban et al. 2004a). These analyses show the strong link between vegetation and $\mathrm{C}$ (organic $\mathrm{C}$ is de- rived from terrestrial and aquatic vegetation while inorganic $\mathrm{C}$ is derive from Charophyceae oospores and stems; Santisteban et al. 2004b). Also N, more abundant in purely aquatic vegetation, is an indicative element of aquatic productivity (Fig. 2). Thus, the relation between inorganic and organic $\mathrm{C}$ gives an indication of the relationship between the aquatic macroalgae and the remaining vegetation while the $\mathrm{N} /$ organic $\mathrm{C}$ ratio gives clues about the ratio of aquatic to emerged vegetation.

\section{Results}

The pollen record can be split in six zones representing different stages of the vegetal cover in the Las Tablas de Daimiel during late Holocene times (Fig. 3).

Zøne $1(100-89.5 \mathrm{~cm})$ shows a landscape dominated by grasslands. The taxa best represented are Asteraceae (liguliflorae and tubuliflorae) and Poaceae followed by Artemisia, Brassicaceae, Chenopodiaceae-Amaranthaceae, Saxifrag a and Rumex. The next group, Shrubs, is dominated by an association of Callun , Juniperus, Pistacia and Rosaceae, replace by Ericaceae towards the top. Trees are represented by Pinus, which is scarce, and minor quantities of evergreen Quercus, which replaces Ulmus. Aquatic taxa are characterised by the relative abundance of $T y$ pha monada and Cyperaceae together with the presence of Pomogeton, Typh tetrada and spores. Sediments are represented by gypsum-rich muds with very low contents of inorganic and organic $\mathrm{C}$ and $\mathrm{N}$.

Zøne A $(89.5-83 \mathrm{~cm})$ shows an increase in arboreal taxa, mainly Pinus and some evergreen Quercus followed by $\mathrm{Ul}$ mus and the presence of Oleaceae. Shrubs are represented by Ericaceae and Cistaceae; there is a minor event that shows a temporary replacement of Cistaceae by Juniperus, Callun and Pistacia. Grassland communities are still dominated by Asteraceae (tubuliflorae and liguliflorae) 
Fig. 3 Pollen diagram (taxa and groups in percentages) of the studied section, organic and inorganic $\mathrm{C}$ and $\mathrm{N}$ content and pollen zones; roman: calibrated ages, italic: linear interpolated ages

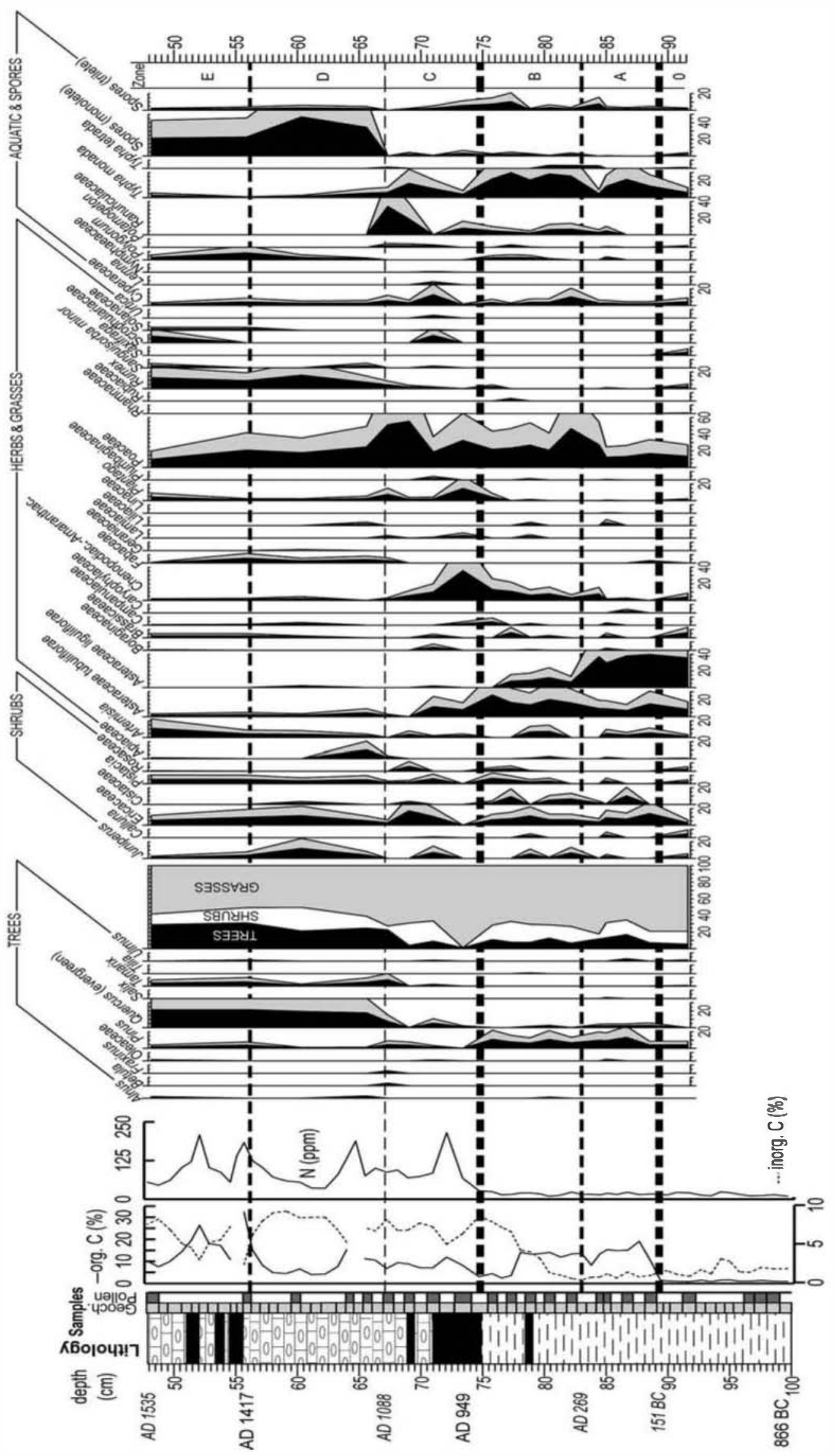


Fig. 4 Vegetation and geochemical indexes related to environmental variables $(*$ : out-of-sequence values; ?: anomalous data, possible human interference) and climatic periods

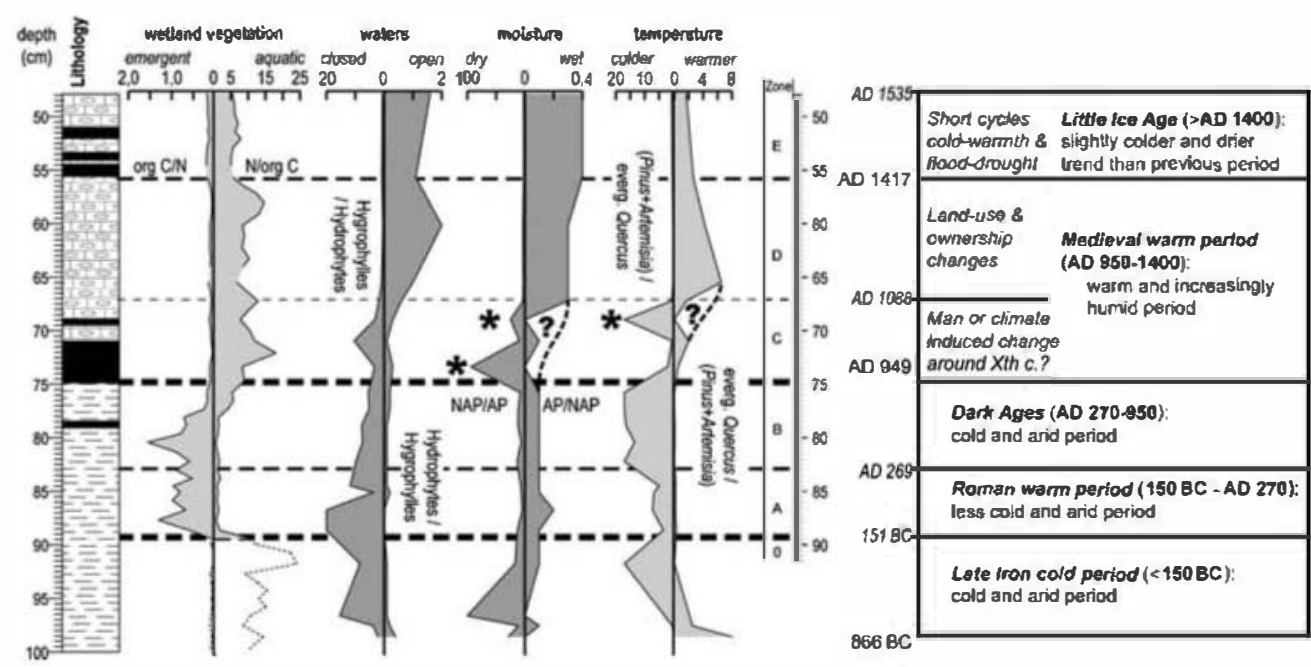

and Poaceae, but there is an evident upwards trend in Chenopodiaceae-Amaranthaceae together with Poaceae. Aquatic taxa show the major changes. This zone opens with a noticeable increase in Typh monada together with Cyperaceae and towards the top this association grows with the incorporation of Ranunculaceae, Polygonum and Potugeton and the spore content increases. This zone marks the base of the organic-rich muds, which is characterised by a sudden increase in organic C, a decrease in gypsum, and low inorganic $\mathrm{C}$ and $\mathrm{N}$ content.

Zone B $(83-75 \mathrm{~cm})$ shows a reduction in arboreal pollen, mainly recorded in the drop of evergreen Quercus. Pinus is still the main taxon and there is a presence of Tilia and Alnus. Shrubs increase slightly; their main association is Ericaceae and Cistaceae together with Juniperus (to the bottom) and Pistacia and Rosaceae (towards the top). Herbs are still the main group but the composition of the association changes. Asteraceae liguliflorae values fall suddenly and Chenopodiaceae-Amaranthaceae, Poaceae and Asteraceae tubuliflorae increase. Artemisia values are still high but fluctuating. The aquatic taxa show the highest values in Typh monada and there is an increase in Cyperaceae, while Ranunculaceae, Polyg num, Pom get $n$ and spores content increase. This zone covers the upper part of the organic-rich muds, characterised by a progressive increase in Charophyceae (inorganic C) and a slight increase in $\mathrm{N}$.

Zone C (75-67 cm) starts with a sudden drop in content of arboreal and shrub pollen. Trees recover slowly with a clear increase in evergreen Quercus accompanied by $P i$ nus (which never reaches its previous values), Tamarix and minor amounts of Oleaceae. Other arboreal taxa present are Ulmus, Betula and Fraxinus. Shrubs are dominated by Ericaceae together with Juniperus and Pistacia and minor quantities of Rosaceae, with a very low component of Callun and Cistaceae. Main features of the grassland community are an important rise in ChenopodiaceaeAmaranthaceae and Poaceae and a decrease in Asteraceae (the liguliflorae forms almost disappear), minimum values of Artemisia, an abrupt increase in Plantage, which shows its maximum values, and an increase in nitrophyllous taxa (Rumex, Sanguisorba minor, Urtica). Of the aquatic taxa, Cyperaceae reaches its maximum values while Typh monada decreases, Ranunculaceae also shows a maximum and is present together with Polygonum, Lemna and a few Nymphaceae; trilete spore values are also the highest. This zone comprises the basal portion of the charophyte mud and sands, which are characterised by high and similar values of inorganic and organic $\mathrm{C}$, plus an increase in the N/organic $\mathrm{C}$ ratio (related to an $\mathrm{N}$ increase in the sediments) and in the average values of the inorganic/organic $\mathrm{C}$ ratio.

Zone D $(67-57 \mathrm{~cm})$ records the rapid spread of evergreen Quercus along with Tamarix and Alnus and the practical disappearance of Pinus. Ericaceae and Juniperus (which reaches its maximum content) dominate the shrubs, followed by Pistacia and traces of Cistaceae, while Callun and Rosaceae disappear. The main change in the grassland community is the drop in Asteraceae (tubuliflorae and liguliflorae) and Chenopodiaceae-Amaranthaceae, which almost disappears, and the decrease in Poaceae and Plantage along with the increase in Artemisia, Rumex and Fabaceae, and the presence of Apiaceae, Brassicaceae, Liliaceae, Campanulaceae and Sanguisor minor. The aquatic taxa suffer major changes as there is a sudden reduction in Typh monada, Typh tetrada is absent, Cyperaceae decreases and Ranunculaceae disappears. On the other hand, Polyg num rises and monolete spores show an abrupt increase (reaching their maximum values). This section of the charophyte muds and sands is characterised by higher values of the ratio inorganic/organic $C$, while the N/organic C ratio shows values similar to the previous zone.

Zone E $(57-48 \mathrm{~cm})$ reintroduces Pinus, along with sparse Ulmus and Oleaceae, in the arboreal assemblage that is composed mainly of evergreen Quercus, with Tamarix and some Alnus. Shrubs show a slight decrease in Ericaceae and, more noticeably, in Juniperus, while Pistacia shows similar values to zone D and Rosaceae reappears. The grassland assemblage is similar to that of zone D. Poaceae decrease and ChenopodiaceaeAmaranthaceae and Asteraceae (liguliflorae disappears) are mere present while Rumex is the main taxon. However there are increases in Artemisia, Plantage, Brassicaceae, Scrophulariaceae and Solanaceae. In the aquatic domain, 
Typh monada recovers slightly but Polyg num is the more representative taxon together with Cyperaceae. Monolete spores decrease noticeably, but not drastically. This is the uppermost part of the charophyte muds and sand studied in this paper and the main change in the composition of the sediment is the higher and fluctuating values of organic $\mathrm{C}$ and $\mathrm{N}$ and the decrease in the $\mathrm{N} /$ organic $\mathrm{C}$ ratio.

\section{Discussion}

The sequence starts, Zone 0 (around 2800-2100 cal B.P. or $<150$ B.C.), with open landscapes, as it is revealed by the very low content of $\mathrm{C}$ and $\mathrm{N}$, dominated by grasslands with sparse trees (Pinus) and shrubs (Calluna). Halophyte taxa, together with Asteraceae and the low values of the arboreal/non-arboreal pollen (AP/NAP) ratio, reveal arid to semiarid conditions and saline soils (Figs. 3 and 4). Similar features have been interpreted as arid conditions in the pollen record from Castillo de Calatrava (GarcíaAntón et al. 1986) and Daimiel II (Menéndez-Amor and Florschütz 1968), where Artemisia and ChenopodiaceaeAmaranthaceae increase simultaneously. This arid phase has also been identified in Tigalmamine (Atlas Range, Morocco) around 2500 to 2000 cal B.P. (Roberts et al. 1994) and in the Ebro Basin (Spain) around 2500 years ago using geomorphological (Gutiérrez-Elorza and Peña-Monné 1998) and other criteria (Davis 1994). It has also been recognised by an arboreal (uercus, Pinus and Salix) retreat in Huelva (SW Spain) around 2200 в.P. (2220 $\pm \mathbf{8 0}$ в.P.; 404-54 в.C.) (Menéndez-Amor and Florschütz 1964) and the beginning of aeolian deposits (dunes) and changes in the wind direction both in SW (Borja et al. 1999) and SE (Goy et al. 1998) Spain around 2700 cal B.P.

Despite such arid conditions, groundwaters were near the surface, as revealed by the association Typha-Cyperaceae and the nitrophyllous taxa, and there were short wet periods that permitted the development of small ponds colonised by aquatic communities composed of Potam g eton and algae.

Despite the low presence of arboreal taxa, the ratio of evergreen Quercus to Pinus and Artemisia seems to indicate a gentle cooling trend and temperatures a little colder than the succeeding episode (Fig. 4).

This event could correspond to the change in solar activity described by van Geel et al. (1999), identified in many places around the world. In Spain it has been identified in the northwest by Desprat et al. (2003) and in the northeast by Gutiérrez-Elorza and Peña Monné (1998). In the Andean region van Geel et al. (2000) recognised it through the analysis of the palaeolimnological, palaeobotanical and glacial records. In raised bogs of England and Ireland, Barber et al. (2003) identified a climatic deterioration around $2700 \mathrm{cal}$ B.P. Also, through analysis of human settlements, colluvial, lake and fluvial deposits, Zolitschka et al. (2003) identified a similar climatic change around the Bronze Age/Iron Age transition.

Recovery of the arboreal taxa in Zone A $(2100-1680 \mathrm{cal}$ B.P., 150 B.C.-A.D. 270), the higher diversity of the aquatic assemblage and the decrease in Callun together with the increase in organic $\mathrm{C}$ (local vegetation-derived organic matter), suggest wetter conditions and a rise of the seasonal water table that allowed the development of wet meadows. This is confirmed by the N/org. C ratio, which indicates emerged vegetation as the main source for the organic matter. The AP/NAP ratio suggests an increase in rainfall although arid conditions still remain. The increase in evergreen Quercus as opposed to the Pinus and Artemisia sum (Fig. 4) reveals slightly higher temperatures. This improvement in the climate has been also identified in NW Spain by Desprat et al. (2003), who assigned it to the Roman Warm Period, but these authors extend this phase until A.D. 450. Roos-Barraclough et al. (2004) identified a similar period (B.C. 40-A.D. 350) in peat humification profiles in Switzerland. McDermott (2004) presents the isotopic record of a stalagmite in southem Ireland where he identifies this period. Also Jiang et al. (2005) recognise this period in a similar time slice from reconstruction of the sea surface temperature off Northem Iceland.

At the start of Zone B (1680-1000 cal B.P., A.D. 270A.D. 950), the rise of the water table allowed the existence of relatively stable water bodies as evidenced by the progressive rise in Charophyceae (inorganic C), aquatic biomass (rising N/organic $\mathrm{C}$ ratio) and the increase in Poaceae, Cyperaceae, Typha, Ranunculaceae, P॰lyg num, Potamoget $n$ and spores (Fig. 3). However the increase in Chenopodiaceae-Amaranthaceae (which reveals the existence of saline soils in the surroundings) together with the almost imperceptible drop of the AP/NAP ratio point to slightly more arid conditions (Fig. 4). The drop in evergreen Quercus together with the constant values of Pinus and Artemisia reveal a climatic deterioration that could be related to slightly lower temperatures assigned by Desprat et al. (2003) to the Dark Ages. Riera et al. (2004) also identified similar conditions, an increase in salinity and more arid conditions, in lakes in NE Spain during their stage viia (A.). 160-820). Roos-Barraclough et al. (2004) also found climatic deterioration centred on A.p. 550 in their Swiss peat humification profiles.

Zone C (1000-860 cal B.P., A.p. 950-1090) data show an important anomaly as arboreal and shrub taxa disappear to the bottom of the zone to recover later and drop again to the top (Figs. 3 and 4). Human influence (Riera et al. 2004) or climatic causes (Desprat et al. 2003) have been invoked to explain similar changes in other areas.

In terms of anthropic influence, the area was entered by Muslims in around the 8th century and was re-conquered by the Christians in late 11 th century. The Muslims introduced water mills and herding so clearance for pasture is a possible explanation for the extremely low values of arboreal and shrub pollen, the increase in Plantage, Boraginaceae, Brassicaceae and Lamiaceae and the presence of Oleaceae and Solanaceae. Also, the fighting that occurred towards the end of this period can explain the "drop" in arboreal and pasture taxa and the relative increase in shrubs at the top of this zone (Fig. 3).

However, this is the period of maximum diversity in the aquatic environment, coinciding with high values of inorganic $\mathrm{C}$ and of the $\mathrm{N} / o r g a n i c ~ C$ ratio (aquatic productivity), 
reflecting an increase in water depth (Fig. 4). The increase in riparian taxa (Poaceae, Cyperaceae and Tamarix) supports this water level rise and, together with the presence of Betula and Fraxinus and the decrease in Asteraceae and Chenopodiaceae-Amaranthaceae, implies a gradual shift to wetter conditions. Also, the higher ratio of evergreen Quercus to Pinus and Artemisia, as seen towards the bottom, may reveal a warming trend that would reach its highest point in Zone D (Fig. 4).

As a hypothesis, this zone records climatic control of the vegetation plus a low intensity of anthropic action.

In Zone D (860-530 cal B.P., A.D. 1090-1400), the no-

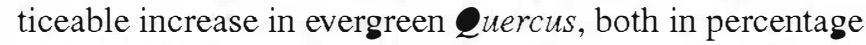
and in absolute numbers, together with an increase in pasture and nitrophyllous taxa reveal a more densely vegetated landscape very similar to the present Spanish "dehesas" (mediterranean forest with Quercus and grasslands used for herding; Fig. 3).

However there are also evident changes in the aquatic environment. The drop in emergent vegetation (Cyperaceae, Typh and Poaceae), the sudden increase in monolete spores, the low diversity in the aquatic taxa and the high inorganic C (Charophyceae) and N/organic C ratio values reveal the expansion of a very productive aquatic environment with a high nutrient load (Fig. 4) that could lead to frequent eutrophication episodes and algal blooms.

These changes are consistent with the warmer and wetter conditions revealed by the increase in the evergreen $\mathbf{Q u e r}$ cus to Pinus and Artemisia and AP/NAP ratios (Fig. 4), similar to those identified as being typically mediterranean by Dorado et al. (2002). Comparable changes are described by Desprat et al. (2003), Julià et al. (1998) and Riera et al. (2004) in NW, central and NE Spain, and these authors recognise this period as the "Medieval Warm Period" (Lamb 1977). This episode is identified at about a similar date all around the world (China: Chu et al. 2002; Arabia: Fleitmann et al. 2004; Africa: Filippi and Talbot 2005; Iceland: Doner 2003; central Europe: Filippi et al. 1999; New Guinea: Haberle and David 2004; USA: Cabaniss Pederson et al. 2005; Argentina: Mauquoy et al. 2004; etc.) and despite particular features, it is characterised by lower climatic variability than other periods.

After A.D. 1400, Zone E, the landscape was very similar to before, but the progressive rise in Pinus and Artemisia indicates lower temperatures (Fig. 3), which are also indicated by fewer eutrophication episoles (monolete spores) and higher accumulation rates of organic matter (sudden increase in organic $\mathrm{C}$ and decrease of the N/organic $\mathrm{C}$ ratio). Despite this the period was still wet (Fig. 4, AP/NAP ratio) and the water table rose. The higher, fluctuating values of organic C (Fig. 3) and the presence of eutrophication episodes indicate frequent alternation of cold and warm periods. These characteristics suggest that this period represents the start of the "Little Ice Age" (Lamb 1977), also identified by Desprat et al. (2003), Julià et al. (1998), Gutiérrez-Elorza and Peña Monné (1998) and Riera et al. (2004) in other records in Spain. This period is consistently found in the sedimentary record and it is characterised by a higher variability in climatic conditions (Adhikari and Kumon 2001; Barber et al. 2003; Lamb et al. 2003; ValeroGarcés et al. 2003; Cabaniss Pederson et al. 2005; Cohen et al. 2005; Dalton et al. 2005; etc.).

\section{Conclusion}

Despite many studies that have pointed to the sun-climate relation (van Geel et al. 1999; Cooper et al. 2000; Dean 2000; Bond et al. 2001; Mauquoy et al. 2002; Labitzke and Matthes 2003; Gimeno et al. 2003; Blaauw et al. 2004; etc.) and the validity of the classical climatic oscillations described for the Late Holocene (Medieval Warm Period, Little Ice Age, etc.) there is a research line that suggests the non-global signature of these periods (IPCC 2001; Jones and Mann 2004).

Looking at Fig. 1 in Mann et al. (1998), the spatial distribution of the proxy series can be seen, allowing for the scarcity of information coming from Mediterranean area. More precisely, in the case of Spain, this information is restricted to two tree-ring series coming from mountain areas.

The best way to solve this controversy would be to increase the number of high-resolution records covering the last millennia and to increase the spatial coverage of these records.

The present paper shows that the record of those Late Holocene climate oscillations identified by other authors in NE and NW Spain can be identified in the Iberian Peninsula interior, and in environments not used until now as highresolution climatic records.

Despite human impact, which most authors agree adds a signal to the pollen record from A.D. 1000, the use of the pollen record together with geochemical parameters permits the identification of five climatic stages for the last 3000 years. These are a cold and arid phase during the Subatlantic (Late Iron Cold Period, < B.C. 150), a warmer and wetter phase (Roman Warm period, B.C. 150-A.D. 270), a new colder and drier period coinciding with the Dark Ages (A.D. 270-900), the warmer and wetter Medieval Warm Period (A.D. 900-1400), and finally a cooling phase (Little Ice Age, > A.D. 1400).

Acknowledgements We acknowledge the Spanish Ministry of Education and Science projects REN2002-04433-CO2-01 and REN2002-04433-CO2-02. The authors are very grateful to the staff of the Las Tablas de Daimiel National Park (Spanish Ministry of the Environment). We are also grateful to the two anonymous reviewers and to John R.G. Daniell whose suggestions have helped to improve the manuscript.

\section{References}

Adhikari DP, Kumon F (2001) Climatic changes during the past 1300 years as deduced from the sediments of Lake Nakatsuna, central Japan. Linmology 2:157-168

Barber KE, Chambers FM, Maddy D (2003) Holocene palaeoclimates from peat stratigraphy: macrofossil proxy climate records from three oceanic raised bogs in England and Ireland. Quat Sci Rev 22:521-539 
Blaauw M, Geel B van, van der Plicht J (2004) Solar forcing of climatic change during the mid-Holocene: indications from raised bogs in The Netherlands. The Holocene 14:35-44

Bond G, Kromer B, Beer J, Muscheler R, Evans MN, Showers W, Hoffmann, Lotti-Bond R, Hajdas I, Bonani G (2001) Persistent Solar Influence on North Atlantic Climate During the Holocene. Science 294:2130-2136

Borja F, Zazo C, Dabrio CJ, Díaz del Olmo F, Goy JL, Lario J (1999) Holocene aeolian phases and human settlements along the Atlantic coast of southern Spain. The Holocene 9:333339

Briffa KR, Osborn TJ (1999) Climate warming: seeing the wood from the trees. Science 284:926

Cabaniss Pederson D, Peteet DM, Kurdyla D, Guilderson T (2005) Medieval warming, Little Ice Age, and European impact on the environment during the last millennium in the lower Hudson Valley, New York, USA. Quat Res 63:238249

Chu G, Li J, Sun O, Lu H, Gu Z, Wang W, Liu T (2002) The 'Mediaeval Warm Period' drought recorded in Lake Huguangyan, tropical South China. The Holocene 12:511516

Cohen AS, Palacios-Fest MR, Msaky ES, Alin SR, McKee B, O'Reilly CM, Dettman DL, Nkotagu H, Lezzar KE (2005) Paleolinmological investigations of anthropogenic environmental change in Lake Tanganyika: IX. Summary of paleorecords of environmental change and catchment deforestation at Lake Tanganyika and impacts on the Lake Tanganyika ecosystem. J Paleolinmol 34:125-145

Cooper MC, O'Sullivan PE, Shine AJ (2000) Climate and solarvariability recorded in Holocene laminated sediments-a preliminary assessment. Quat Int 68-71:363-371

Dalton C, Birks HJB, Brooks SJ, Cameron NG, Evershed RP, Peglar SM, Scott JA, Thompson R (2005) A multi-proxy study of lake-development in response to catchment changes during the Holocene at Lochnagar, north-east Scotland. Palaeogeogr Palaeoclimatol Palaeoecol 221:175-201

Davis BAS (1994) Palaeolinnology and Holocene environmental change from endorheic lake in Ebro Basin, North-East Spain. UnpublishedPh.D. Thesis, University of Newcastle UptonTyne,

Dean WE (200) The Sun and Climate. USGS Fact Sheet FS- $\mathbf{0 9 5 - 0 0}$

Desprat S, Sánchez-Goñi MF, Loutre MF (2003) Revealing climatic variability of the last three millennia in northwestern Iberia using pollen influx data. Earth Planet Sci Lett 213:63-78

Doner L (2003) Late-Holocene paleoenvironments of northwest Iceland from lake sediments. Palaeogeogr Palaeoclimatol Palaeoecol 193:535-560

Dorado-Valiño M, Valdeolmillos A, Ruiz-Zapata B, Gil-García MJ, Bustamante I (1999) Evolución climática durante el Holocenoen la cuenca alta del Guadiana (Submeseta sur ibérica). Cuaternario y Geomorfología 13:19-32

Dorado-Valiño M, Valdeolmillos A, Ruiz-Zapata MB, GilGarcía MJ, Bustamante I (2002) Climatic changes since the Lateglacial/Holocene transition in La Mancha plain (South Central Iberian Peninsula, Spain) and their evidence in The Tablas de Daimiel marshlands. Quat Int 93-94:73-84

Faegri K, Iversen J, Kaland PE, Krzywinski K (1989) Textbook of pollen analysis, 4 th edn. Wiley, London

Filippi ML, Lambert P, Hunziker J, Kübler B, Bemasconi S (1999) Climatic and anthropogenic influence on the stable isotope record from bulk carbonates and ostracodes in Lake Neuchâtel, Switzerland, during the last two millennia. J Paleolinmol 21:1934

Filippi ML, Talbot MR (2005) The palaeolinmology of northern Lake Malawi over the last $25 \mathrm{ka}$ based upon the elemental and stable isotopic composition of sedimentary organic matter. Quat Sci Rev 24:1303-1328

Fleitmann D, Bums SJ, Neff U, Mudelsee M, Mangini A, Matter A (2004) Palaeoclimatic interpretation of high-resolution oxygen isotope profiles derived from annually laminated speleothems from Southern Oman. Quat Sci Rev 23:935-945
Folland CK, Karl TR, Clıristy JR, Clarke RA, Gruza GV, Jouzel J, Mann ME, Oerlemans J, Salinger MJ, Wang S-W (2001) Observed climate variability and change. In: Houghton JT, Ding Y, Griggs DJ, Noguer M, van der Linden PJ, Dai X, Maskell $\mathrm{K}$, Johnson CA (eds) Climate Change 2001: The Scientific Basis. Contribution of Working Group I to the Third Assessment Report of the Intergovernmental Panel on Climate Change. Cambridge University Press, Cambridge, pp 99-181

García-Antón M, Morla C, Ruiz-Zapata B, Sainz-Ollero H (1986) Contribución al conocimiento del paisaje vegetal Holoceno en la Submeseta Sur Ibérica: analisis polínico de sedimentos hidroturbososen el Campo de Calatrava, Ciudad real, España. In: López-Vera (ed) Quatemary climate in westem Mediterranean. Universidad Autónoma, Madrid, pp 189-203

Geel B van, Raspopov OM, Renssen H, van der Plicht J, Dergachev VA, Meijer HA (1999) The role of solar forcing upon climate change. Quat Sci Rev 18:331-338

Geel B van, Heusser CJ, Renssen H, Schuurmans CJE (2000) Climatic change in Chile at around $2700 \mathrm{BP}$ and global evidence for solar forcing: a hypothesis. The Holocene 10:659664

Gimeno L, de la Torre L, Nie to R, García R, Hernández E, Ribera P (2003) Changes in the relationship NAO-Northern hemisphere temperature due to solar activity. Earth Planet Sci Lett 206:1520

González-Alvarez R, Bernárdez P, Pena LD, Francés G, Prego R, Diz P, Vilas F (2005) Paleoclimatic evolution of the Galician continental shelf (NW of Spain) during the last 3000 years: from a storm regime to present conditions. J Mar Syst 54:245-260

Goy JL, Zazo C, Dabrio CJ, Baena J, Harvey AM, Silva PG, González F, Lario J (1998) Sea level and climate changes in the Cabo de Gata lagoon (Almeria) during the last $6000 \mathrm{yr}$ BP. INQUA Mediterr Blacksea Shorelines Subcomm Newslett 20:239251

Gutiérrez-Elorza M, Peña-Monné JL (1998) Geomorphology and Late Holocene climatic change in Northeastern Spain. Geomorphology 23:205-217

Haberle SG, David B (204) Climates of change:human dimensions of Holocene environmental change in low latitudes of the PEPII transect. Quat Int 118-119:165-179

IPCC (2001) Climate Change 2001: The Scientific Basis. Contribution of Working Group I to the Third Assessment Report of the Intergovernmental Panel on Climate Change

Jiang H, Eiriksson J, Schulz M, Knudsen K-L, Seidenlrantz M-S (2005) Evidence for solar forcing of sea-surface temperature on the North Icelandic Shelf during the late Holocene. Geology 33:73-76

Jones PD, Mann ME (2004) Climate over past millennia. Reviews of Geophysics 42, doi: 10.1029/2003RG000143

Julià R, Burjachs F, DasíMJ, Mezquita F, Miracle MR, Roca JR, Seret G, Vicente E (1998) Meromixis origin and recent trophic evolution in the Spanish mountain lake La Cruz. Aqua Sci 60:279299

Labitzke K, Matthes K (2003). Eleven-year solar cycle variations in the atmosphere: observations, mechanisms and models. The Holocene 13:311-317

Lamb H (1977) Climate: Present, Past and Future, vol. 2. Climatic History and the Future, Methuen

Lamb H, Darbyshire I, Verschuren D (2003) Vegetation response to rainfall variation and human impact in central Kenya during the past 1100 years. The Holocene 13:285-292

Luque JA, Julià R (2002) Lake sediment response to land-use and climate change during the last 1000 years in the oligotrophic Lake Sanabria (northwest of Iberian Peninsula). Sediment Geol 148:343-355

Mann ME, Bradley RS, Hughes MK (1998) Global-scale temperature patterns and climate forcing over the past six centuries. Nature 392:779-787

Martínez-Cortizas A, Pontevedra Pombal X, García-Rodeja E, Nóvoa Muñoz JC, Shotyk W (1999) Mercury in a Spanish peat bog: archive of climate change and atmospheric metal deposition. Science 284:939-942 
Mauquoy D, Geel B van, Blaauw M, vander Plicht J(2002) Evidence from northwest European bogs shows 'Little Ice Age' climatic changes driven by variations in solar activity. The Holocene $12: 1-6$

Mauquoy D, Blaauw M, Geel B van, Borromei A, Quattrocchio M, Chambers F, Possnert G (2004) Late Holocene climatic changes in Tierra del Fuego based on multiproxy analyses of peat deposits. Quat Res 61:148-158

McCormac FG, Reimer PJ, Hogg AG, Higham TFG, Baillie MGL, Palmer J, St uiver M (2002) Calibration of the Radiocarbon Time Scale for the Southern Hemisphere: AD 1850-950. Radiocarbon 44:641-651

McDermott F (2004) Palaeo-climate reconstruction from stable isotope variations in speleothems: a review. Quat Sci Rev 23:91918

McIntyre S, McKitrick R (2003) Corrections to the Mann et al. (1998) Proxy Data Base and Northern Hemispheric Average Temperature Series. Energy Environ 14:751-771

McIntyre S, McKitrick R (2005) The M\&M critique of the MBH98 northern hemisphere climate index: update and implications. Energy Environ 16:69-100

Menéndez-Amor J, Florschütz F (1964) Resultados del análisis paleobotánico de una capa de turba en las cercanías de Huelva (Andalucia). Estudios Geológicos 20:183-186

Menéndez-Amor J, Florschütz F (1968) Estudio palinológico de la turbera de Daimiel. La Préhistoire. Problèmes et tendances, CNRS, Paris, pP 291-294

Moore PD, Webb JA, Collinson ME (1991) Pollen Analysis. Blackwell Scientific Publications, Oxford

Peinado-Lorca M, Rivas-Martínez S (1987) La vegetación de España. Servicio de Publicaciones de la Universidad de Alcalá. Madrid

R Development Core Team (2005) R: a language and environment for statistical computing. R Foundation for Statistical Computing, Vienna, Austria. http://www.R-project.org

Reille M (1990) Leçón de Palynologie et d'analyse pollinique. Editions du CNRS, Paris

Riera S, Wansard G, Julià R (2004) 2000-year environmental history of a karstic lake in the Mediterranean Pre-Pyrenees: the Estanya lakes (Spain). Catena 55:293-324

Roberts N, Lamb HF, El Hamonti N, Barker P (1994) Abrupt Holocene hydroclimatic events palaeolirmological evidence from North-West Africa. In: Millington AC, Pye K (eds) Environmental change in drylands: biogeographical and geomorphological perspectives. Wiley, Chicester, pp 163-175

Roos-Barraclough F, van der Knaap WO, van Leeuwen JFN, Shotyk W (2004) A Late-glacial and Holocene record of climatic change from a Swiss peat humification profile. The Holocene 14:7-19

Santisteban JI, Mediavilla R, López-Pamo E, Dabrio C, Ruiz Zapata MB, Gil García MJ, Castaño E, Martínez-Alfaro PE (2004a) Loss on ignition: a qualitative or quantitative method for organic matter and carbonate mineral content in sediments? J Paleolimnol 32:287-299
Santisteban JI, López Pamo E, Mediavilla López R, RuizZapata MB, Gil García MJ, Dabrio CJ (2004b) Carbon fixation on wetland environments during recent times. 32th Intemational Geological Congress, Firenze, Italy. Abstracts: 733

Soon W, Baliunas S (2003) Proxy climatic and environmental changes of the past 1000 years. Clim Res 23:89-110

Soon W, Baliunas S, Idso C, Idso S, Legates DR (2003) Reconstructing climatic and environmental changes of the past 1000 years: a reappraisal. Energy Environ 14:233-296

Stuiver M, Braziunas TF (1993) Modeling a mospheric ${ }^{14} \mathrm{C}$ influences and ${ }^{14} \mathrm{C}$ ages of marine samples to $10,000 \mathrm{BC}$. Radiocarbon 35:137-89

Stuiver M, Reimer PJ (1993) Radiocarbon calibration program rev. 3.0.3. Radiocarbon 35:215-230

Stuiver M, Reimer PJ, Bard E, Beck JW, Burr GS, Hughen KA, Kromer B, McCornac G, van der Plicht J, Spurk M (1998a) Intcal98 radiocarbon age calibration, $24,000-0 \mathrm{cal}$ BP. Radiocarbon 40:1041-1083

Stuiver M, Reimer PJ, Braziunas TF (1998b) High precision radiocarbon age calibration for terrestrial and marine samples. Radiocarbon 40:1127-1151

St uiver M, Reimer PJ, Reimer R (2003) CALIB Radiocarbon Calibration, version 4.4. University of Washington Quaternary Isotope Lab (QIL, Available: www.calib.org/)

Valdeohnillos A, Dorado-Valiño M, Ruiz-Zapata B, Bardají T, Bustamante I (2003) Palaeoclimatic record of the Last Glacial Cycle at The Las Tablas de Daimiel Nacional Park (Southem Iberian Meseta, Spain). In: Ruiz-Zapata B, Dorado-Valiño M, Valdeolmillos A, Gil-García MJ, Bardají T, Bustamante I, Martínez I (eds) Quaternary climatic changes and environmental crises in the Mediterranean region. Alcalá de Henares, Madrid, PP 221-228

Valero-Garcés B, Kelts K, Delgado-Huertas A, González-Sampériz P, Navas A, Machín J (1999) Sedimentary facies analices as paleohydrology proxies for saline lakes, Centro Ebro Basin, Spain. Terra Nostra 99:101-106

Valero-Garcés BL, González-Sampériz P, Delgado-Huertas A, Navas A, Machín J, Kelts K (2000) Lateglacial and Late Holocene environmental and vegetational change in Salada Mediana, central Ebro Basin, Spain. Quat Int 73/74:29-46

Valero-Garcés BL, Delgado-Huertas A, Navas A, Edwards L, Schwalb A, Ratto N (2003) Pattems of regional hydrological variability in central-southern Altiplano $\left(18^{\bullet}-26^{\bullet} \mathrm{S}\right)$ lakes during the last 500 years. Palaeogeog Palaeoclimatol Palaeoecol 194:319-338

Watts WCJ (1973) Rates of changes and stability in vegetation in the perspective of long periods of time. In: Birks HJB, West RG (eds) Quatemary Plant Ecology. Blackwell, Oxford, pp 195-206

Zolitschka B, Behre K-E, Schneider J (2003) Human and climatic impact on the environment as derived from colluvial, fluvial and lacustrine archives---examples from the Bronze Age to the Migration period, Gemany. Quat Sci Rev 22:81-1 6 